\title{
Optimization of Bioinsecticides Overproduction by Bacillus thuringiensis subsp. kurstaki Using Linear Regression
}

\author{
KARIM ENNOURI ${ }^{1}$, HANEN BEN HASSEN ${ }^{2}$ and NABIL ZOUARI ${ }^{1,3 *}$ \\ ${ }^{1}$ Team of Biopesticides (LPIP), Centre of Biotechnology of Sfax, University of Sfax, Tunisia \\ ${ }^{2}$ Unit of biostatistics and Bioinformatics, Centre of Biotechnology of Sfax, University of Sfax, Tunisia \\ ${ }^{3}$ Biological \& Environmental Sciences Department, College of Arts and Sciences. \\ Qatar University, Qatar
}

Submitted 1 December 2012, accepted 15 July 2013

\begin{abstract}
A multiple linear regression analyses were performed to screen for the significant factors simultaneously influencing production of deltaendotoxin, proteolytic activities and spore formation by a Bacillus thuringiensis kurstaki strain. Investigated factors included: $\mathrm{pH}$ of the medium, available oxygen and inoculum size. It was observed that oxygen availability was the most influencing setting on both deltaendotoxins production and spores counts, followed by initial $\mathrm{pH}$ of the medium and inoculum size. On other hand, $\mathrm{pH}$ of medium was found to be the most significant parameter for proteolytic activity, followed by inoculum size and dissolved oxygen. Our results suggested that the first order with two-factor interaction model seemed to be more satisfactory than simple first order model for optimization of delta-endotoxin overproduction. The coefficients of determination $\left(\mathrm{R}^{2}\right)$ indicated a better adequacy of the second order models to justify the obtained data. Based on results, relationships between delta-endotoxins production, proteolytic activities and spores counts were established. Our results can help to balance delta-endotoxins production and its stability.
\end{abstract}

Ke y w ords: Bacillus thuringiensis kurstaki, delta-endotoxins, multiple linear regression, proteases, spores

\section{Introduction}

Bacillus thuringiensis is an aerobic, Gram-positive and spore-forming bacterium. B. thuringiensis grows under aerobic conditions with few nutrient requirements (Zouari et al., 2002). After exhaustion of one or more nutrients, B.thuringiensis produces a spore and parasporal crystal proteins (also called deltaendotoxins) exhibiting insecticidal activity with high specificity to insects larvae belonging to Lepidoptera, Diptera, Coleoptera, Hymenoptera, Orthoptera orders (Feitelson, 1993). B.thuringiensis production, especially concerning the spore-crystal complex, depends principally on the composition of the culture medium components and fermentation conditions (Ghribi et al., 2007a). Furthermore, some studies had shown that B. thuringiensis bioinsecticides production is achieved by significant levels of enzymes in the growth media (Zouari and Jaoua, 1999; Chen et al., 2004). The production and secretion of enzymes by microorganisms is induced by medium ingredients and other physical factors such as inoculum size and available oxygen
(Celik and Calik, 2004; Singh et al., 2004). Proteolytic activities are essential to assimilate proteins as nitrogen source, but they are involved in the stability of proteins produced by the bacterium as metabolites. In our previous work (unpublished), we showed that a strong relationship exists between accumulation of delta-endotoxins of B.thuringiensis and the available proteolytic activities in the medium. It is then necessary to establish a balanced system in which the synthesis and accumulation of delta-endotoxins in the fermentation broth is not counteracted by of proteolytic activity of $B$. thuringiensis.

There is a common interest to investigate such balance. It is still difficult to predict simultaneously yields of multiple bioproducts using a given set of cultivation parameters. Multiple linear regression is a statistical method used to analyse the relationship between one response variable (dependent variable) with two or more variables (independent variables). If the relation between the dependent and other independent variables could be found using multiple linear regression, a better control strategy could be sought.

* Corresponding author: N. Zouari, Biological \& Environmental Sciences Department, College of Arts and Sciences. Qatar University, P.O.Box: 2713-Doha, Qatar; phone: (+974)4403-4559; e-mail address: nabil.zouari@qu.edu.qa 
The aim of this study was to optimise external factors which play an important role in improving the production of $B$.thuringiensis delta-endotoxins and to find the relationship between the most important parameters which are the inoculum size, initial $\mathrm{pH}$ and available oxygen, then to predict delta-endotoxins, proteases concentrations and spores counts using multiple linear regression. The optimisation process was carried out by development of mathematic equations characterizing the experimental results as a function of the factor level.

\section{Experimental}

\section{Materials and Methods}

Microorganisms. The bacterial strain S7 was isolated and identified as B. thuringiensis kurstaki in our laboratory. It was shown that it exhibits promising potentials in pest caterpillars control (data unpublished). The strain was maintained by streak inoculating on Luria Broth (LB) nutrient plates $(\mathrm{g} / \mathrm{l})$ : yeast extract 5 , peptone $10, \mathrm{NaCl} 5$ and agar 15 , incubated at $30^{\circ} \mathrm{C}$ for $24 \mathrm{~h}$ and stored at $4^{\circ} \mathrm{C}$ for further use.

Inocula preparation method. Inocula were prepared as follows: one isolated colony was dispensed in $3 \mathrm{ml}$ of LB medium and incubated overnight at $30^{\circ} \mathrm{C}$. $0.5 \mathrm{ml}$ were used to inoculate $250 \mathrm{ml}$ shake flasks containing $50 \mathrm{ml} \mathrm{LB}$ medium. After $6 \mathrm{~h}$ of incubation at $30^{\circ} \mathrm{C}$ in $200 \mathrm{rev} / \mathrm{min}$ in a rotary shaker (New Brunswick Scientific, Edison, NJ, USA), the culture broth was used to inoculate the media. The O.D. ${ }_{600}$ was determined using a SmartSpec ${ }^{\mathrm{TM}} 3000$ UV-visible spectrophotometer (Bio-Rad Laboratories).

Cultures conditions. B. thuringiensis strain was grown in complex medium for delta-endotoxin production. Economic complex medium (Ghribi et al., 2007b) contained (g/l): soybean flour, 25; starch, 30; $\mathrm{K}_{2} \mathrm{HPO}_{4}, 1 ; \mathrm{KH}_{2} \mathrm{PO}_{4}, 1 ; \mathrm{MgSO}_{4} \cdot 7 \mathrm{H}_{2} \mathrm{O}, 0.3 ; \mathrm{MnSO}_{4}$, $0.1 ; \mathrm{FeSO}_{4}, 0.1$. The initial $\mathrm{pH}$ was adjusted and $\mathrm{CaCO}_{3}$ $(20 \mathrm{~g} / \mathrm{l})$ were added for maintaining $\mathrm{pH}$ value. All flasks are sterilized at $121^{\circ} \mathrm{C}$ for $20 \mathrm{~min}$. Shake flask cultures were hold in shake flasks containing $25 \mathrm{ml}$ of medium and incubated at $30^{\circ} \mathrm{C}$ on a rotary shaker at $200 \mathrm{rev} /$ $\min$ for $72 \mathrm{~h}$.

Quantification of delta-endotoxin production. Crystal proteins were solubilized before protein concentration assay. Crystal-spore pellets were washed twice with $1 \mathrm{M} \mathrm{NaCl}$ and twice with bi-distilled water. Samples were incubated in $0.05 \mathrm{M} \mathrm{NaOH}$ ( $\mathrm{pH}$ 12.5) for $2 \mathrm{~h}$ at $30^{\circ} \mathrm{C}$ in a rotary shaker $(200 \mathrm{rev} / \mathrm{min})$. Obtained fraction was collected by centrifugation with $13000 \times \mathrm{g}$ for $10 \mathrm{~min}$. The supernatant, containing the alkali-soluble insecticidal crystal proteins was used to estimate delta-endotoxin concentration by Bradford method (Bradford, 1976), using bovine serum albumin (BSA) as a protein standard. Samples were measured after $10 \mathrm{~min}$ at $595 \mathrm{~nm}$. The values are the average of three measures of two separate runs.

Proteolytic activity assay. Protease activity was determined according to modified Kunitz method (Kunitz, 1946). Supernatant of culture medium was diluted with Tris-HCl buffer $\mathrm{pH}$ 7.0. Proteolytic activity was assayed by incubating $1 \mathrm{ml}$ diluted enzyme solution with $1 \mathrm{ml}$ casein $(1 \% \mathrm{w} / \mathrm{v})$ for $20 \mathrm{~min}$ at $60^{\circ} \mathrm{C}$. The reaction was stopped by adding $3 \mathrm{ml}$ of $5 \%$ trichloroacetic acid (TCA). The mixture was incubated for $30 \mathrm{~min}$ to precipitate the total non-hydrolysed proteins and peptides. Blanks were prepared with inactivated enzymes containing supernatants. After the incubation, samples and blanks were centrifuged at $13000 \times \mathrm{g}$, for $15 \mathrm{~min}$. The absorbance of the samples was measured at $280 \mathrm{~nm}$. One unit of protease activity (U) was defined as the amount of enzyme that hydrolyzed casein to produce $1 \mu \mathrm{g}$ of tyrosin within $1 \mathrm{~min}$ at $60^{\circ} \mathrm{C}$. The presented values are the average of three measures of two separate runs.

Viable spore count. Viable spore counts from the bacterial culture were measured by colony counting after heating the culture sample at $80^{\circ} \mathrm{C}$ for $10 \mathrm{~min}$ in order to destroy vegetative cells, The LB plates were incubated at $30^{\circ} \mathrm{C}$ for $24 \mathrm{~h}$. Colonies were counted and statistically analysed (and expressed as c.f.u. $\mathrm{ml}^{-1}$ ). The values are the mean of three determinations of two separate runs.

Effect of aeration, inoculum volume and initial $\mathrm{pH}$ on B. thuringiensis production. The effect of aeration on B. thuringiensis subsp. kurstaki was determined by growing the strain S7 into various shake flask volumes $(250 \mathrm{ml}, 500 \mathrm{ml}$ and $1000 \mathrm{ml})$ and constant medium volume of $25 \mathrm{ml}$. Consequently, the quotient, corresponding to the volume of air in the flask compared to culture volume, was equal to 9,19 and 39 . The initial $\mathrm{pH}$ was adjusted to $6.5,7.0$ or 7.5 in order to investigate the effect of various initial $\mathrm{pH}$ on B. thuringiensis bioinsecticides production. The optical density at $600 \mathrm{~nm}$ of the inoculum prepared in LB medium, was measured and calculated volumes were used to inoculate the cultures with inoculum sizes of $0.100,0.150$ and 0.200 , corresponding to $1.35 \times 10^{8}, 2 \times 10^{8}$ and $2.7 \times 10^{8}$ cells $/ \mathrm{ml}$ respectively.

Linear Regression model. The purpose of the model is the recovery of specific information about the culture conditions influenced by several variables observed simultaneously and the estimation of the dependent variable from the other observed independent variables. The multiple regression analyses were conducted to establish prediction equations (Minitab Inc., State College, PA). 


\section{Results and Discussion}

Multiple linear Regression analysis. Regression analysis demonstrates the statistical relationship between one or more parameters and the response variable to forecast new observations. The output is expressed as a simple linear model such as $Y=\beta_{0}+\beta_{1} x_{1}+\beta_{2} x_{2}+\beta_{3} x_{3}$ $+\varepsilon$, where $Y$ is the dependent (response) variable. The variables to be predicted are $\beta_{0}, \beta_{1}, \beta_{2}$ and $\beta_{3}$, are empirical constants and $\mathrm{x}_{1}, \mathrm{x}_{2}$ and $\mathrm{x}_{3}$ are the parameters influencing the studied response and with the error term $\varepsilon$.

Regression results define the statistical significance, direction and size of the relationship between a parameter and the response. Sign of each coefficient suggests the direction of the relationship. The coefficients describe the change in the response for one unit of change in the predictor while considering other parameters in the model constant. The significance of coefficients was estimated by student's t-test and p-values. The higher the level of the t-value and the lower the $\mathrm{p}$-value, the more significant is the coefficient (Khuri and Cornell, 1987).

Three multiple linear correlations were tested in which, delta-endotoxins concentration $\left(\mathrm{Y}_{1}\right)$, proteases concentration $\left(\mathrm{Y}_{2}\right)$ and spore counts $\left(\mathrm{Y}_{3}\right)$ are the dependent variables. The applicable range of all the parameters of the regression model is the following: optical density of inoculum varied from 0.10 to 0.20 , available oxygen quotient, varied from 9 to 39 , and the initial $\mathrm{pH}$ medium varied from 6.5 to 7.5 .
Results of delta-endotoxins productions, proteolytic activity and spores counts depending on culture parameters ( $\mathrm{pH}$, available oxygen and inoculum volume) are presented in Table I. Delta-endotoxin concentrations ranged from $2597 \mathrm{mg} / \mathrm{l}$ to $3464.68 \mathrm{mg} / \mathrm{l}$, enzymatic activity values varied from $434.09 \mathrm{U} / \mathrm{ml}$ to $954.55 \mathrm{U} / \mathrm{ml}$ whereas spores counts ranged from $70 \times 10^{7}$ c.f.u. $/ \mathrm{ml}$ to $150 \times 10^{7} \mathrm{c}$.fu. $/ \mathrm{ml}$ according the experimental conditions. Regression coefficients and corresponding t-values for the model were obtained which are shown in Table II. The regression model proposed for estimation of delta-endotoxin production is as follows:

$$
\mathrm{Y}_{1}(\mathrm{mg} / \mathrm{l})=4465+13.4 \mathrm{x}_{1}-326 \mathrm{x}_{2}+3080 \mathrm{x}_{3} \text { (Eq. 1) }
$$

Where $\left(\mathrm{x}_{1}\right)$ is the available oxygen ratio, $\left(\mathrm{x}_{2}\right)$ is initial $\mathrm{pH}$ medium and $\left(\mathrm{x}_{3}\right)$ is the optical density at $600 \mathrm{~nm}$ of inoculum $\left(\mathrm{OD}_{600}\right)$. The analysis of multiparametric function, such as the example shown in Table II, indicates its adequacy, with a satisfactory $\mathrm{R}^{2}(72.5 \%)$. Analysis of the $p$-values indicates the level of significance of each effect. Effects with p-value $<0.05$ are highly significant. p-value $<0.1$ shows a moderate significant effect and $p$-value $<0.2$ suggests that the effect can be considered (Moita et al., 2005). The p-values for all variables are less than $5 \%$. The $\mathrm{p}$-values indicate that $\mathrm{x}_{1}$ was the most significant $(p=0.001)$, followed by $x_{2}(p=0.005)$ and $\mathrm{x}_{3}(\mathrm{p}=0.018)$ in multiple linear correlations.

Trials and results for proteolytic activities of $B$. thuringiensis are showed in Table I. The regression coefficients and $\mathrm{t}$-values for the model were obtained (Table II).

Table I

Study of the effects of oxygen, initial $\mathrm{pH}$ of medium and optical density (OD) of inoculum at $600 \mathrm{~nm}$ on delta-endotoxin productions, proteolytic activity and spores counts.

\begin{tabular}{|c|c|c|c|c|c|}
\hline Volume & $\mathrm{pH}$ & OD inoculum & $\begin{array}{l}\text { Delta-endotoxins } \\
\text { production }(\mathrm{mg} / \mathrm{l})\end{array}$ & $\begin{array}{l}\text { Proteolytic activity } \\
\qquad(\mathrm{U} / \mathrm{ml})\end{array}$ & $\begin{array}{c}\text { Spores counts } \\
\left(10^{7} / \mathrm{ml}\right)\end{array}$ \\
\hline 39 & 7.5 & 0.1 & $2597.01 \pm 85.7$ & $434.09 \pm 20.5$ & $100 \pm 5$ \\
\hline 19 & 7 & 0.15 & $2711.93 \pm 61.3$ & $556.82 \pm 13.7$ & $120 \pm 7$ \\
\hline 9 & 7.5 & 0.15 & $2748.1 \pm 87.7$ & $625 \pm 23.9$ & $140 \pm 5$ \\
\hline 9 & 6.5 & 0.15 & $2783.47 \pm 44.36$ & $534.09 \pm 22$ & $130 \pm 4$ \\
\hline 9 & 7.5 & 0.2 & $2783.47 \pm 86.6$ & $954.55 \pm 27.4$ & $146 \pm 6$ \\
\hline 19 & 7.5 & 0.2 & $2788.97 \pm 43.34$ & $727.27 \pm 17.8$ & $147 \pm 2$ \\
\hline 19 & 7.5 & 0.1 & $2789.59 \pm 62.74$ & $545.45 \pm 19.18$ & $100 \pm 5$ \\
\hline 9 & 7 & 0.15 & $2803.83 \pm 43.85$ & $572.73 \pm 26$ & $150 \pm 7$ \\
\hline 19 & 6.5 & 0.1 & $2858.82 \pm 60.6$ & $472.73 \pm 21.9$ & $94 \pm 5$ \\
\hline 39 & 7.5 & 0.15 & $2908.7 \pm 61.3$ & $615 \pm 11$ & $89 \pm 6$ \\
\hline 19 & 6.5 & 0.15 & $3029.19 \pm 91.9$ & $440.91 \pm 27.27$ & $90 \pm 5$ \\
\hline 39 & 7 & 0.1 & $3031.18 \pm 43.85$ & $545.45 \pm 16.36$ & $70 \pm 7$ \\
\hline 19 & 6.5 & 0.2 & $3244.83 \pm 85.7$ & $436.36 \pm 20$ & $90 \pm 3$ \\
\hline 39 & 7 & 0.2 & $3289.78 \pm 62$ & $545.45 \pm 23.18$ & $95 \pm 5$ \\
\hline 39 & 7 & 0.15 & $3415.19 \pm 89.8$ & $477.27 \pm 20.45$ & $97 \pm 5$ \\
\hline 39 & 6.5 & 0.15 & $3464.68 \pm 94.11$ & $488.64 \pm 15$ & $96 \pm 4$ \\
\hline
\end{tabular}


Table II

Regression results of delta-endotoxins and proteases concentrations, and colonies forming units (c.f.u./ml)

\begin{tabular}{|c|c|c|c|c|c|c|c|c|c|}
\hline \multirow{2}{*}{ Term } & \multicolumn{3}{|c|}{ Delta endotoxins } & \multicolumn{3}{|c|}{ Proteases } & \multicolumn{3}{|c|}{ Colonies forming units (c.f.u./ml) } \\
\hline & Coefficient & $\begin{array}{l}\text { Standard } \\
\text { effect (t) }\end{array}$ & $\mathrm{p}$-value & Coefficient & $\begin{array}{l}\text { Standard } \\
\text { effect }(\mathrm{t})\end{array}$ & $\mathrm{p}$-value & Coefficient & $\begin{array}{l}\text { Standard } \\
\text { effect }(\mathrm{t})\end{array}$ & $\mathrm{p}$-value \\
\hline Constant & 4464.8 & 6.47 & 0.000 & -851.5 & -2.20 & 0.048 & -38.33 & -0.60 & 0.562 \\
\hline $\mathrm{x}_{1}$ & 13.390 & 4.11 & 0.001 & -3.240 & -1.77 & 0.102 & -1.3626 & -4.49 & 0.001 \\
\hline $\mathrm{x}_{2}$ & -326.43 & -3.46 & 0.005 & 181.66 & 3.43 & 0.005 & 21.794 & 2.48 & 0.029 \\
\hline \multirow[t]{2}{*}{$\mathrm{x}_{3}$} & 3080 & 2.73 & 0.018 & 1421.8 & 2.25 & 0.044 & 182.8 & 1.74 & 0.108 \\
\hline & \multicolumn{3}{|c|}{$\begin{array}{l}\mathrm{S}=155.757 \\
\mathrm{R}^{2}=72.5 \% \\
\mathrm{R}^{2} \text { (adjusted) }=65.6 \%\end{array}$} & \multicolumn{3}{|c|}{$\begin{array}{l}\mathrm{S}=87.4089 \\
\mathrm{R}^{2}=64.5 \% \\
\mathrm{R}^{2} \text { (adjusted) }=55.7 \%\end{array}$} & \multicolumn{3}{|c|}{$\begin{array}{l}\mathrm{S}=14.5134 \\
\mathrm{R}^{2}=73.5 \% \\
\mathrm{R}^{2} \text { (adjusted) }=66.9 \%\end{array}$} \\
\hline
\end{tabular}

The regression model proposed for determination of protease concentration is shown in Equation (2):

$$
\mathrm{Y}_{2}(\mathrm{U} / \mathrm{ml})=-851-3.24 \mathrm{x}_{1}+182 \mathrm{x}_{2}+1422 \mathrm{x}_{3} \text { (Eq. 2) }
$$

The regression results in Table II reveal that the correlation yields a $R^{2}$ value of 0.645 , which means that the proposed model can explain $64.5 \%$ variation in the response. The $\mathrm{p}$-values reveal that $\mathrm{x}_{2}(\mathrm{p}=0.005)$ was highly significant, followed by $\mathrm{x}_{3}(\mathrm{p}=0.044)$, while $\mathrm{x}_{1}$ showed a moderate significant effect $(\mathrm{p}=0.102 \geq 0.1)$. It can be seen that the available air has a negative effect and $\mathrm{pH}$ of the medium and inoculum size have positive effect, which means that an increase in the inoculum size and/or $\mathrm{pH}$ of the medium and a decrease of the available oxygen lead to improve enzymatic activity. Table II shows the variables effects on spore counts. The regression model for determination of spore counts is presented in Equation (3):

$$
\left.\mathrm{Y}_{3}\left(10^{7} / \mathrm{ml}\right)=-38.3-1.36 \mathrm{x}_{1}+21.8 \mathrm{x}_{2}+183 \mathrm{x}_{3} \text { (Eq. } 3\right)
$$

In the multiple linear correlation (Table II), the correlation yields the smallest $\mathrm{R}^{2}$ of $73.5 \%$. Additionally, $\mathrm{p}$-value for the slopes of two parameters $\left(\mathrm{x}_{1}\right.$ and $\left.\mathrm{x}_{2}\right)$ are less than $5 \%$, these $\mathrm{p}$-values indicate that the parameters are significant variables in this correlation. The $\mathrm{p}$-value of inoculum $\left(\mathrm{x}_{3}\right)$ indicates the relative significance volume in variation of spores counts $(p=0.108 \geq 0.1)$.

Data analysis shows that oxygen was found to enhance the delta-endotoxins contents. However, it has an inhibitory effect on both proteolytic activity and spores counts. Foda et al. (1985) noted the failure of the organism to sporulate under low aeration levels. In other study, Maldonado-Blanco et al. (2003) obtained the most toxic $B$. thuringiensis bioinsecticide producted at high aeration rates, in spite of inhibition of sporulation.

The effect of initial $\mathrm{pH}$ of medium on delta-endotoxins production was also examined. The results indicate that it exhibits a supressive effect at high levels, on delta-endotoxins production but improves protease activity and spores counts. In fact, Alves et al. (1997) stated that the culture medium should be brought to neutral $\mathrm{pH}$ at harvest because high $\mathrm{pH}$ is optimal for Bacillus thuringiensis proteases and potentially damaging to the crystals. Furthermore, Ejiofor and Okafor (1989) concluded that low $\mathrm{pH}$ can restrain growth, sporulation and crystal formation of B. thuringiensis. Likewise, the volume of inoculum used for the production of crystal-spore complex has no significant effect on delta-endotoxins formation. High initial cell concentration in the production medium may result in a rapid consumption of oxygen and other nutrients. During fermentation, B. thuringiensis produces different types of proteases which can be supplied for the hydrolysis of protein components in the medium to amino acids that can be used for the microbial growth of B. thuringiensis and synthesis of useful metabolites (Tyagi et al., 2002). Besides, proteolytic activity kept on increasing until the end of fermentation process and could be due to the lysis of sporulated cells and release of intracellular proteases into the medium (Zouari and Jaoua, 1999). In addition, we conclude that it is recommended to use small amount of inoculum to limit the proteolytic action of secreted enzymes on crystals. Similarly, this explains previous results reported by Zouari et al. (1998).

The study of parameters involved in delta-endotoxins concentrations, protease concentrations and spores counts showed that sporulation phenomenon is strongly related with production of $B$. thuringiensis proteolytic enzymes. In fact, the sporulation stage in $B$. thuringiensis is marked by the synthesis of many types of proteins, including proteases (Bibilos and Andrews, 1988). Sporulation process is characterized by protein turnover as there is development of cortex and spore coats interfered by intracellular proteases.

Normal probability plot of residuals. Figure 1 shows the normal probability plot of the residuals for delta-endotoxins (a), proteases (b) and spores counts, expressed by colonies forming units (c). It can be seen 

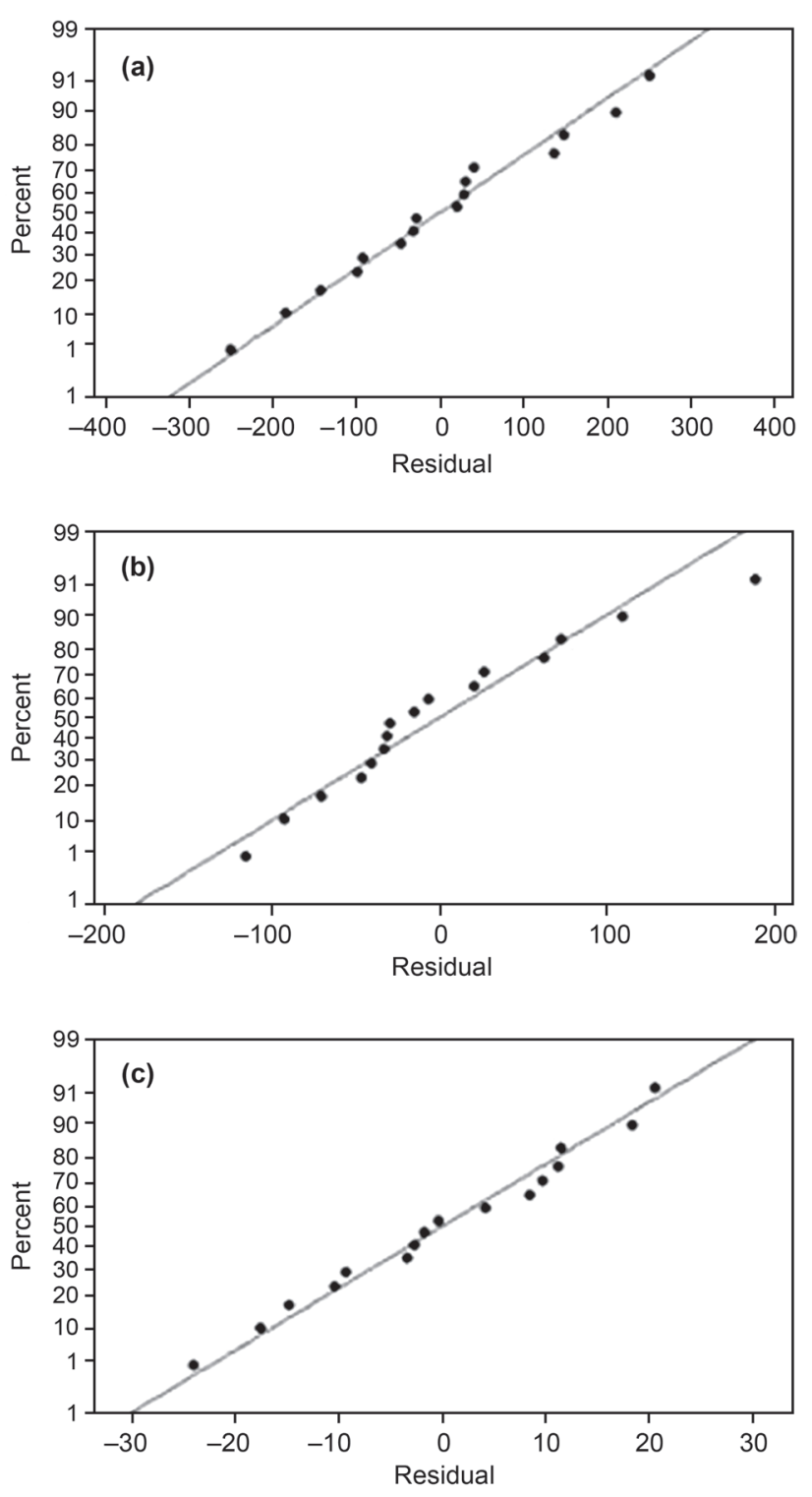

Fig. 1. Normal probability plot for the production of delta-endotoxins (a), proteases (b) and spores counts (c). that for all the responses, the points fall close to the straight line. Hence, the data from the essays come from a normally distributed set. Normal probability plots are a graphical method for verifying the normality of the residuals. As seen in the figure, the normality assumption was reasonably satisfied as the points in the plot form straight line. All of the plots show that model is satisfactory to illustrate the final bacterial products (crystal proteins, proteases and spores) by multiple linear regression.

Development of regression model equation. In order to study the combined effects of the studied factors, experiments were performed for various combinations of the parameters using statistical methods. The model for multiple linear regression given $\mathrm{n}$ observations is: $\mathrm{Y}=\beta_{0}+\beta_{1} \mathrm{x}_{\mathrm{i} 1}+\beta_{2} \mathrm{x}_{\mathrm{i} 2}+\ldots \beta_{\mathrm{p}} \mathrm{x}_{\text {ip }}+\varepsilon_{\mathrm{i}}$, where $\mathrm{Y}$ is the dependent variable, $\beta_{0}$ is the intercept, $\beta_{1}, \beta_{2}$ and $\beta_{\mathrm{p}}$ are the regression coefficient of each independent variable included in the regression model and $\varepsilon_{\mathrm{i}}$ is the random error term.

The different coefficients of the regression function, the $t$ and $p$-values for delta-endotoxins, proteases and spores counts are presented in Table III. The polynomial equations for delta-endotoxins (Eq. 4), proteases (Eq. 5) and spores counts (Eq. 6) in terms of coded factors are given as following:

$$
\begin{aligned}
& \mathrm{Y}_{4}(\mathrm{mg} / \mathrm{l})=-1140+157 \mathrm{x}_{1}+525 \mathrm{x}_{2}+17195 \mathrm{x}_{3} \\
& \left.-22.0 \mathrm{x}_{1} \mathrm{x}_{2}+77.1 \mathrm{x}_{1} \mathrm{x}_{3}-2361 \mathrm{x}_{2} \mathrm{x}_{3} \text { (Eq. } 4\right) \\
& \mathrm{Y}_{5}(\mathrm{U} / \mathrm{ml})=2212+31.30 \mathrm{x}_{1}-285 \mathrm{x}_{2}-21844 \mathrm{x}_{3} \\
& \left.-3.40 \mathrm{x}_{1} \mathrm{x}_{2}-63.90 \mathrm{x}_{1} \mathrm{x}_{3}+3486 \mathrm{x}_{2} \mathrm{x}_{3} \text { (Eq. } 5\right) \\
& \mathrm{Y}_{6}\left(10^{7} / \mathrm{ml}\right)=230-0.16 \mathrm{x}_{1}-16.3 \mathrm{x}_{2}-1770 \mathrm{x}_{3} \\
& -0.154 \mathrm{x}_{1} \mathrm{x}_{2}-0.3 \mathrm{x}_{1} \mathrm{x}_{3}+275 \mathrm{x}_{2} \mathrm{x}_{3} \text { (Eq. 6) }
\end{aligned}
$$

\begin{tabular}{|c|c|c|c|c|c|c|c|c|c|}
\hline \multirow{2}{*}{ Term } & \multicolumn{3}{|c|}{ Delta endotoxins } & \multicolumn{3}{|c|}{ Proteases } & \multicolumn{3}{|c|}{ Colonies forming units (c.f.u./ml) } \\
\hline & Coefficient & $\begin{array}{l}\text { Standard } \\
\text { effect }(\mathrm{t})\end{array}$ & p-value & Coefficient & $\begin{array}{l}\text { Standard } \\
\text { effect }(t)\end{array}$ & p-value & Coefficient & $\begin{array}{l}\text { Standard } \\
\text { effect }(\mathrm{t})\end{array}$ & p-value \\
\hline Constant & -1140 & -0.41 & 0.692 & 2212 & 1.58 & 0.148 & 230.5 & 0.63 & 0.546 \\
\hline $\mathrm{x}_{1}$ & 156.97 & 3.07 & 0.013 & 31.30 & 1.22 & 0.254 & -0.158 & -0.02 & 0.982 \\
\hline $\mathrm{x}_{2}$ & 524.6 & 1.33 & 0.216 & -285.1 & -1.44 & 0.184 & -16.32 & -0.31 & 0.761 \\
\hline $\mathrm{x}_{3}$ & 17195 & 1.11 & 0.295 & -21844 & -2.81 & 0.020 & -1770 & -0.87 & 0.408 \\
\hline $\mathrm{x}_{1} \mathrm{x}_{2}$ & -22.036 & -3.16 & 0.012 & -3.398 & -0.97 & 0.357 & -0.1536 & -0.17 & 0.871 \\
\hline $\mathrm{x}_{1} \mathrm{x}_{3}$ & 77.13 & 0.94 & 0.371 & -63.90 & -1.55 & 0.155 & -0.33 & -0.03 & 0.976 \\
\hline \multirow[t]{2}{*}{$\mathrm{x}_{2} \mathrm{x}_{3}$} & -2361 & -1.10 & 0.301 & 3486 & 3.23 & 0.010 & 275.3 & 0.97 & 0.357 \\
\hline & \multicolumn{3}{|c|}{$\begin{array}{l}\mathrm{S}=119.954 \\
\mathrm{R}^{2}=87.7 \% \\
\mathrm{R}^{2} \text { (adjusted }\end{array}$} & \multicolumn{3}{|c|}{$\begin{array}{l}\mathrm{S}=60.22 \\
\mathrm{R}^{2}=87.4 \% \\
\mathrm{R}^{2} \text { (adjusted) }=78.9 \%\end{array}$} & \multicolumn{3}{|c|}{$\begin{array}{l}S=15.8087 \\
R^{2}=76.4 \% \\
R^{2} \text { (adjusted) }=60.7 \%\end{array}$} \\
\hline
\end{tabular}

It is observed in Table III that low $\mathrm{p}$-value $(\mathrm{p}=0.013)$ of $\left(x_{1}\right)$ confirms highly significance of this factor for delta-endotoxins production. The effect of $\left(\mathrm{x}_{1} \mathrm{x}_{2}\right)$

Table III

Estimated regression coefficients for delta-endotoxins concentrations, proteases and colonies forming units (c.f.u./ml) in coded units. 
interaction has high influence on delta-endotoxin production $(p=0.012)$. In this case, the $p$-value $(p \leq 0.05)$ in both responses for regression model equation implies that the polynomial model fitted well with the experimental results. However, $\left(\mathrm{x}_{2}\right),\left(\mathrm{x}_{3}\right)$ and all interaction terms (except $\mathrm{x}_{1} \mathrm{x}_{2}$ ) were insignificant to the delta-endotoxins production. Furthermore, according to results of Table III, low $\mathrm{p}$-values of $\left(\mathrm{x}_{3}\right)$, confirm highly significant effect of this factor for protease activity in the culture broth $(p=0.020<0.05)$. Likewise, the effects of $\mathrm{x}_{2} \mathrm{x}_{3}$ (p-value of 0.010 ) can be considered as highly significant. It was found that $\mathrm{x}_{1}, \mathrm{x}_{2}$ and all interaction terms (except $\mathrm{x}_{2} \mathrm{x}_{3}$ ) were insignificant to this response. On other hand, the regression analysis of spores counts results shown in Table III reveals that all terms are insignificant because of their high p-values ( $p>0.05)$.

Similarly, variables effects and variable interactions on delta-endotoxins productions, proteolytic activity and spore counts of $B$.thuringiensis were analysed. It can be seen that $\left(\mathrm{x}_{1}\right)$ has active effect, while $\left(\mathrm{x}_{1} \mathrm{x}_{2}\right)$ interaction denoted inhibitory effect on twice deltaendotoxins and proteases productions. All the other parameters have opposite effect on delta-endotoxins and proteases production. Finally, most parameters have similar negative effects on both protease activities and spores counts, except positive effect of $\left(\mathrm{x}_{1}\right)$ on proteolytic activity. In the same way, only $\left(\mathrm{x}_{2} \mathrm{x}_{3}\right)$ has positive effect on proteolytic activity and spores counts. That suggests more associated relationships between proteolytic enzymes secretions and spores forming compared to delta-endotoxins concentrations. In fact, Freese and Heinze (1984) showed that high protease excretion by some Bacillus species starts during the sporulation phase. The relationship implying deltaendotoxins concentrations and proteolytic activities may be explained by the "disrupted action" of proteases on delta-endotoxins.

Additionally, $\mathrm{R}^{2}$ values of $87.7 \%, 87.4 \%$ and $76.4 \%$ for delta-endotoxin concentration, proteolytic activity and spores counts, respectively, express high correlations between the observed and predicted values. Besides, an enhancement of coefficient of determination values in developed regression models confirms more accurate representative models of the experimental data, considering parameters interactions, compared to simple regression models.

According to the coefficients of determination values, the responses showed that the linear terms of the medium $\mathrm{pH}$, initial inoculum volume, available oxygen and the interactions, have notable effects on deltaendotoxins, proteases production and spores formation. It implies that interaction effects of studied parameters were evident on production of delta-endotoxins, proteolytic enzymes secretion and spores counts by $B$. thuringiensis kurstaki. Moreover, this study proves that first order with two factor interactions model could be used in order to exhibit the possible relationships existing between the studied parameters and the effects on the responses. These methods are helpful for improving the accuracy of analytical predictive models in case of $B$. thuringiensis kurstaki studies.

In this work, multiple linear regression were used to test the relative importance of culture settings (initial $\mathrm{pH}$, available oxygen and inoculum volume) on different microbial final products (delta-endotoxins, proteases and spores). Simple linear regression results suggested that the studied parameters have significant influence on bioinsecticides production. Furthermore, available oxygen and inoculum size showed a moderate significant effect on proteolytic activity and spores counts respectively. All other parameters showed high significant effect on twice proteolytic activity and spores counts. The study of multiple linear regressions of proposed models, including interactions parameters, reveals that negative interaction between available oxygen and initial $\mathrm{pH}$ must be considered for delta-endotoxins production. In addition, interaction between inoculum and initial $\mathrm{pH}$ showed a positive significant effect on proteolytic activity. The regression relations may be used to forecast concentrations of various $B$. thuringiensis products during fermentation. The regression equations presented in this study are specific for B. thuringiensis strain. It is important to note that these statements are suitable within the lower and upper limits of the factors: initial $\mathrm{pH}(6.5-7.5)$, optical density at $600 \mathrm{~nm}$ of inoculum size (0.10-0.20) and available oxygen ratio (oxygen volume /culture volume) (9-39).

\section{Acknowledgments}

This study was supported by grants from the "Tunisian Ministry of Higher Education, Scientific Research and Technology".

\section{Literature}

Alves L.F.A., S.B. Alves, R.M. Pereira and D.M.F. Capalbo. 1997. Production of Bacillus thuringiensis var. kurstaki Berliner grown in alternative media. Biocontrol Sci. Techn. 7: 377-384.

Bibilos M. and R.E. Andrews. 1988. Inhibition of Bacillus thuringiensis proteases and their effects on crystal toxin proteins and cell free translations. Can. J. Microbiol. 34: 740-747.

Bradford M. 1976. A rapid and sensitive method for the quantitation of microgram quantities of protein utilizing the principle of protein-dye binding. Anal. Biochem. 72: 248-254.

Celik E. and P. Calik. 2004. Bioprocess parameters and oxygen transfer characteristics in beta-lactamase production by Bacillus species. Biotechnol. Prog. 20: 491-499.

Chen C.Y., Y.H. Wang and C.J. Huang. 2004. Enhancement of the antifungal activity of Bacillus subtilis F29-3 by the chitinase encoded by Bacillus circulans chiA gene. Can. J. Microbiol. 50: 451-454.

Ejiofor A.O. and N. Okafor. 1989. Production of mosquito larvicidal Bacillus thuringiensis serotype $\mathrm{H}-14$ on raw material media from Nigeria. J. Appl. Bacteriol. 67: 5-9. 
Feitelson J.S. 1993. The Bacillus thuringiensis family tree, pp. 63-72. In: Kim L. (ed). Advanced Engineered Pesticides. Marcel Dekker Inc. New York.

Foda M.S., H.S. Salama and M. Selim. 1985. Factors affecting growth physiology of Bacillus thuringiensis. Appl. Microbiol. Biotechnol. 22: 50-52.

Freese E. and J. Heinze. 1984. Metabolic and genetic control of bacterial sporulation, pp.101-172. In: Hurst A., G.W. Gould and J. Dring (eds). The Bacterial spores. Academic Press, London.

Ghribi D., N. Zouari, H. Trabelsi and S. Jaoua. 2007a. Improvement of Bacillus thuringiensis delta-endotoxin production by overcome of carbon catabolite repression through adequate control of aeration. Enzyme Microb. Technol. 40: 614-622.

Ghribi D., N. Zouari, W. Trigui and S. Jaoua. 2007b. Use of sea water as salts source in starch and soya bean based media for production of Bacillus thuringiensis bioinsecticides. Process Biochem. 42: 374-378.

Khuri A.I. and J.A. Cornell. 1987. Response surfaces: Design and analyses. Marcel Dekker Inc., New York.

Kunitz M. 1946. Crystalline soybean trypsin inhibitor. J. Gen Physiol. 29: 149-154.

Maldonado-Blanco M.G., G. Solis-Romero and L.J. Galan-Wong. 2003. The effect of oxygen tension on the production of Bacillus thuringiensis subs. israelensis toxin active against Aedes aegypti larvae. World J. Microbiol. Biotechnol. 19: 671-674.
Moita C., S. Savluchinske Feio, L. Nunes, M. Joao Marcelo Curto and J.C. Roseiro. 2005. Optimization of physical factors on the production of active metabolites by $B$. subtilis 355 against wood surface contaminant fungi. Int. Biodeter. Biodegr. 55: 261-269.

Singh J., R.M. Vohra and D.K. Sahoo. 2004. Enhanced production of alkaline proteases by Bacillus sphaericus using fed-batch culture. Process Biochem. 39: 1093-1101.

Tyagi R.D., V. Sikati Foko, S. Barnabé, A. Vidyarthi, J.R. Valéro and R.Y. Surampalli. 2002. Simultaneous production of biopesticide and alkaline proteases by Bacillus thuringiensis using sludge as a raw material. Water Sci. Technol. 46: 247-254.

Zouari N., O. Achour and S. Jaoua. 2002. Production of deltaendotoxin by Bacillus thuringiensis subsp kurstaki and overcoming of catabolite repression by using highly concentrated gruel and fish meal media in 2-and 20- $\mathrm{dm}^{3}$ fermenters. J. Chem. Technol. Biotechnol. 77: 877-882.

Zouari N. and S. Jaoua. 1999. Production and characterization of metalloproteases synthesized concomitantly with delta-endotoxin by Bacillus thuringiensis subsp. kurstaki strain grown on gruel based media. Enzyme Microb. Tech. 25: 364-371.

Zouari N., A. Dhouib, R. Ellouz and S. Jaoua. 1998. Nutritional requirements of a strain of Bacillus thuringiensis subsp. kurstaki and use of gruel hydrolysate for the formulation of a new medium for delta-endotoxin production. Appl. Biochem. Biotech. 69: 41-52. 